\title{
Geothermal energy for better integration with other renewable energy sources
}

\author{
Prof. Trupti Deoram Tembhekar [Prof. Trupti Jayant Sakhare], Dr.S.N.Dhurvey
}

\begin{abstract}
Geothermal power plants utilize hydrothermal resources that contain both heat (thermal) and water (hydro). Geothermal power generation is valued for its high reliability, independence from short term weather fluctuations, and long operating life. The total installed capacity for global geothermal power generation was estimated to be around 14.06 gigawatts (GW). Geothermal power runs at a much higher load factor than wind or solar, so geothermal produces significantly more electricity per megawatts (MW) of capacity. Geothermal power has considerable potential for growth as the amount of heat within 10,000 metres of the earth's surface is estimated to contain 50,000 times more energy than all oil and gas resources worldwide.
\end{abstract}

Index Terms - Geothermal, GSI, gigawatts, SONATA, MW, Hydropower, Dry steam, turbine.

\section{INTRODUCTION}

Geothermal energy is the heat that comes from the sub-surface of the earth. It is contained in the rocks and fluids beneath the earth's crust and can be found as far down to the earth's hot molten rock, magma. To produce power from geothermal energy, wells are dug a mile deep into underground reservoirs to access the steam and hot water there, which can then be used to drive turbines connected to electricity generators. Dry steam is the oldest form of geothermal technology and takes steam out of the ground and uses it to directly drive a turbine. Flash plants use high-pressure hot water into cool, low-pressure water whilst binary plants pass hot water through a secondary liquid with a lower boiling point, which turns to vapour to drive the turbine.

\section{PRODUCTION OF GEOTHERMAL ENERGY}

To produce geothermal-generated electricity, wells, sometimes a mile (1.6 kilometres) deep or more, are drilled into underground reservoirs to tap steam and very hot water that drive turbines linked to electricity generators. There are three types of geothermal power plants: dry steam, flash, and binary. Dry steam, the oldest geothermal technology, takes steam out of fractures in the ground and uses it to directly drive a turbine. Flash plants pull deep, high-pressure hot water into cooler, low-pressure water. The steam that results from this process is used to drive the turbine. In binary plants, the hot water is passed by a secondary fluid with a much lower boiling point than water. This causes the secondary fluid to turn to vapour, which then drives a turbine. Most geothermal power plants in the future will be binary plants.

The 340 springs are grouped into seven geothermal provinces. Himalayan (Puga, Chhumathang), Sohana belt in Haryana, Cambay Graben basin, Son-Narmada-Tapi (SONATA) lineament belt, West Coast, Godavari basin and
Mahanadi basin. Some of the prominent geothermal resources include the Puga valley and Chhumathang in Jammu and Kashmir, Manikaran in Himachal Pradesh, Ratnagiri in Maharashtra, Tattapani in Chhattisgarh and Tapoban in Uttarakhand

\section{ANALYSIS OF GEOTHERMAL ENERGY}

The first project will test deployment of a dense array of seismic sensors to improve the ability to image where and how fluids are moving underground. The second project will develop and apply modeling tools to enable geothermal plants to safely run in flexible (or variable) production mode, allowing for better integration with other renewable energy sources. India is looking to geothermal energy to help in reaching its goal of getting half of its electricity from renewable sources by the year 2030. Geothermal plants are possible only in locations with particular geological characteristics, either near active volcanic centers or in places with a very high temperature gradient.

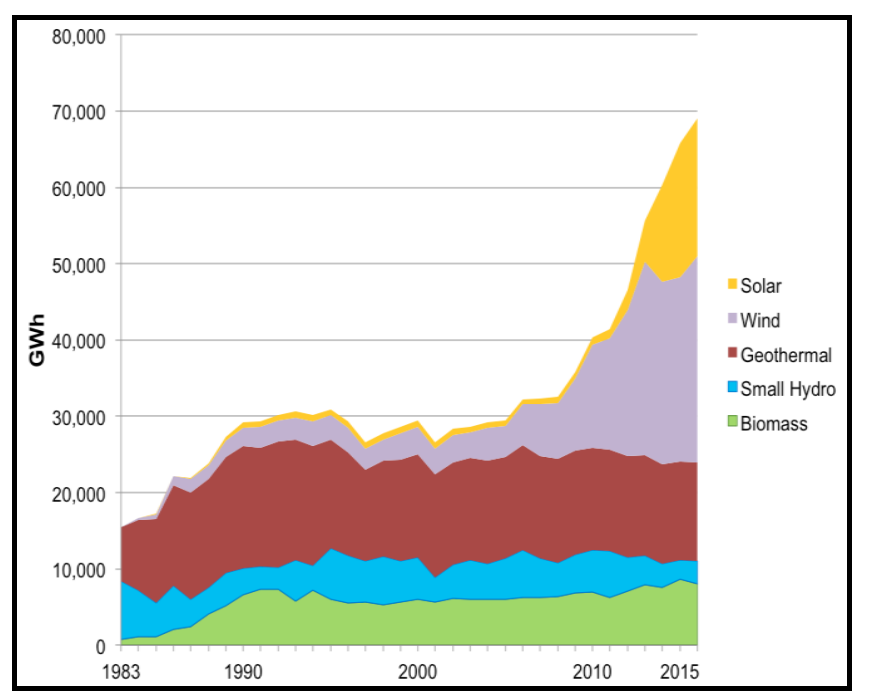

Figures 1:- Data Analysis of Geothermal Energy

\section{INDIAN GEOTHERMAL SCENARIO}

India has a huge potential to become a leading contributor in generating eco-friendly and cost-effective geothermal power. The GSI (Geological Survey of India) has identified 340 geothermal energy locations in the country. Most of these locations are in the low to medium temperature range, that is, from $35-98^{\circ} \mathrm{Cwhich}$ is suitable for direct heat applications.

On the basis of enthalpy characteristics the geothermal systems in India, are classified into medium $\left(100^{\circ} \mathrm{C}-200^{\circ} \mathrm{C}\right)$ and low enthalpy $\left(<100^{\circ} \mathrm{C}\right)$ geothermal energy 
resources/systems. Medium enthalpy geothermal energy systems are associated with younger intrusive granites (a sin Himalayas), major tectonic features/lineaments and rifts and grabens. The Low enthalpy geothermal energy systems are associated with Tertiary tectonics and neo-tectonic activity. With India's geothermal power potential of 10,600 MW, the following are the potential sources/regions where geothermal energy can be harnessed in India.

\section{UTTARAKHAND STATE OVERVIEW}

There are 62 thermal spring localities in Uttrakhand, all of them are confined to the Himalayan terrain, which lie in the altitude range of $1000 \mathrm{~m}-4000 \mathrm{~m}$ above mean sea level and occupy 10-40 km wide zone along all the major valleys, viz., Kali, Alaknanda, Mandakini, Bhilangua, Bhagirathi, Yamuna and Tons. Of the 62 thermal spring localities, 37 occur in the Central Crystalline (Proterozoic) and 22 in the Garhwal Group of rocks (Precambrian) on either side of the Main Central Thrust (MCT). The remaining three localities occur in the Tethyan Himalaya. The thermal springs occurring within the Central Crystalline show high temperatures of $55^{\circ} \mathrm{C}$ to $94^{\circ} \mathrm{C}$, while a majority of the manifestations ( 16 out of 22 ), in the Garhwals show low temperatures of $38^{\circ} \mathrm{C}$ to $22^{\circ} \mathrm{C}$. Most of the thermal springs emerge through joints and or are controlled by the interfaces of the litho logical units.

Secondary deposits associated with the thermal manifestation comprise mainly thin carbonate encrustations/ layers. The chemistry of the thermal water indicates that a majority of the thermal discharges are either of $\mathrm{Ca} \mathrm{Mg} \mathrm{HCO3,}$ or of $\mathrm{Na} \mathrm{HCO3}$ type with exceptions are the Gangnani and Jamnotri.

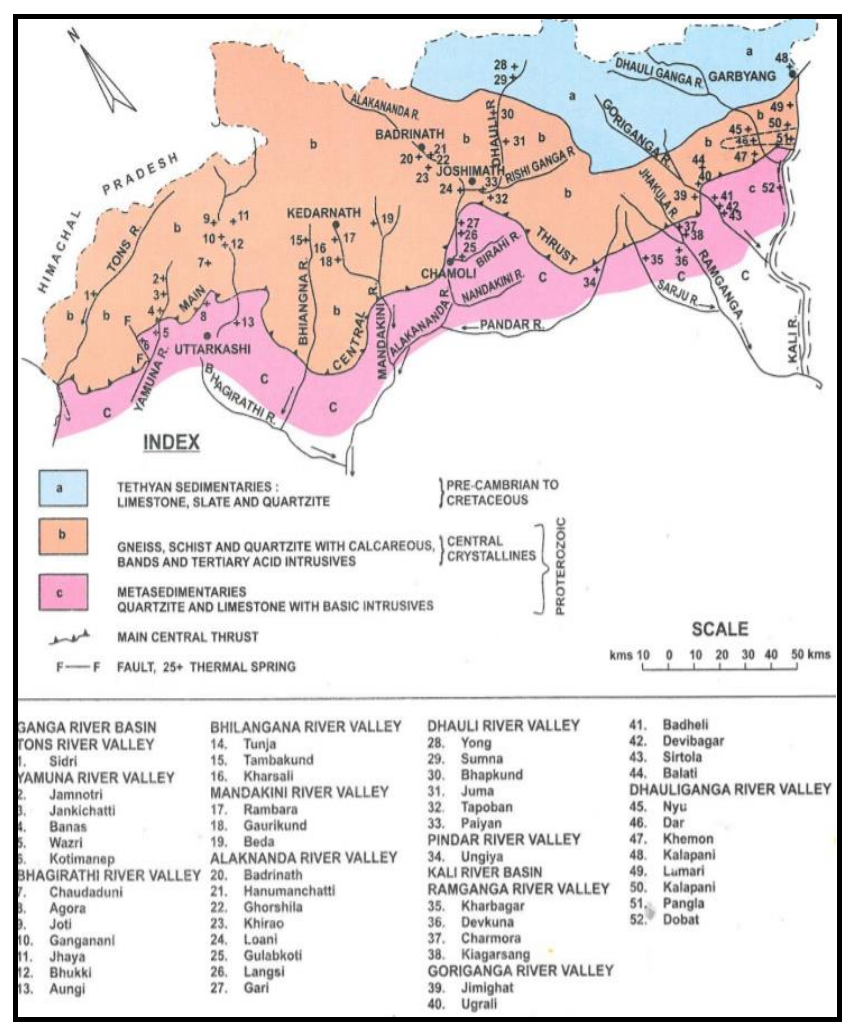

Figures 2:- Geological map of Uttarakhand showing the distribution of hot springs

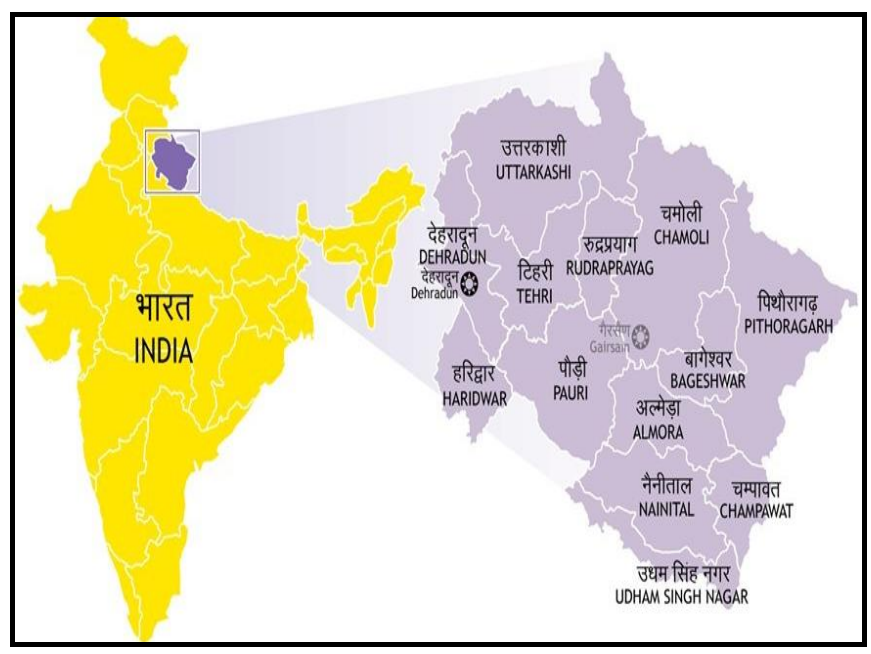

Figures 3:- Uttarakhand Snapshot

\section{SITE INFORMATION}

\begin{tabular}{|c|c|}
\hline Power Plant Name & Geothermal Power Plant \\
\hline Location & $\begin{array}{c}\text { Tapoban in Chamoli district, } \\
\text { Uttrakhand }\end{array}$ \\
\hline Unit Capacity & Approximately 20 MW \\
\hline Focus Sector & Geothermal \\
\hline Project Timelines & 8 years \\
\hline Highest temperature & $65^{\circ} \mathrm{C}$ \\
\hline Discharge from Springs & $\begin{array}{c}\text { Varies between } 0.83-9.22 \\
\text { lit/sec }\end{array}$ \\
\hline Elevation & $1920 \mathrm{~m}$ \\
\hline Thermal Efficiency Rate & $10-23 \%$ \\
\hline Proposed Land Area & Tapoban, Chamoli district \\
\hline
\end{tabular}

\section{TAPOBAN GEOTHERMAL AREA, DISTRICT CHAMOLI}

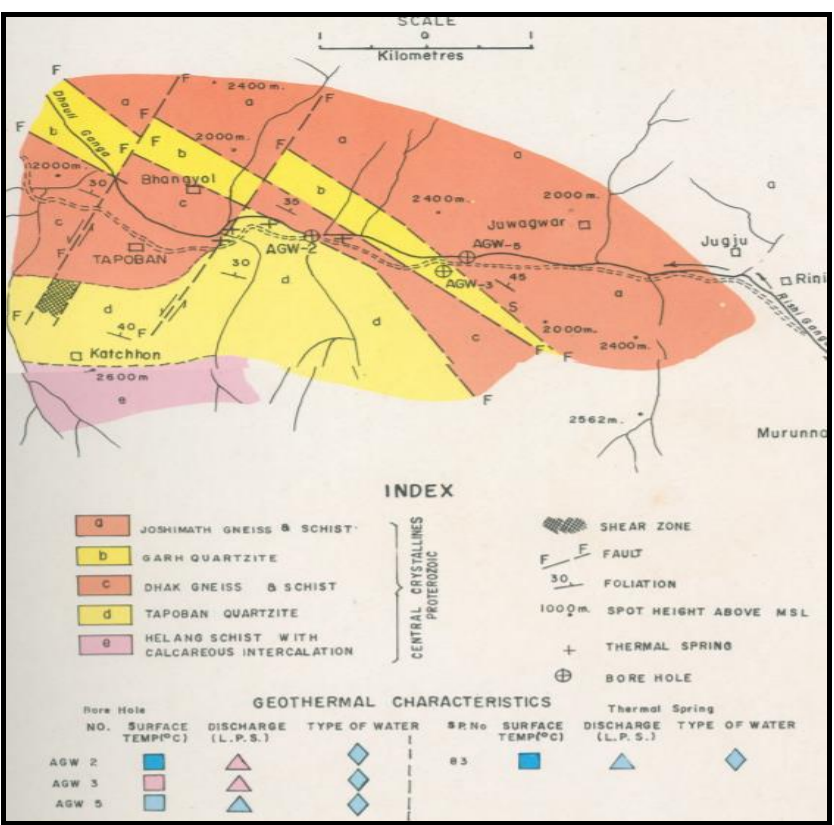

Figures 4:- Tapoban geothermal area, District Chamoli 


\section{CONCLUSION}

Uttarakhand is being developed as energy state to tap the hydro power electric potential of over 25,000 MW. The state has a stable political environment with successive governments that have been committed towards creating a progressive business environment. The state has abundant natural resources due to hills and forests and vast water resources favouring Hydropower and Geothermal Power Generation. The Industrial electricity tariff in Uttarakhand is one of the lowest across the States. The electricity supply is reliable. This site profile is based on preliminary study to facilitate prospective entrepreneurs to assess a prima facie scope. It is, however, advisable to get a detailed feasibility study prepared before taking a final investment decision.

\section{ACKNOWLEDGMENT}

This paper owes its completion to the guidance of many and without their help it would not have been possible to move ahead.

I would like to express our deepest appreciation to our project guide for constant guidance and support. The valuable suggestions have contributed in every way for shaping this work. Without supervision and encouragement this paper would have not been materialized.

I would thank to our Head of Department of Electrical Engineering as she has been a constant source of inspiration.

I would like to express our gratitude to Hon'ble Shri. Dattaji Meghe, Chairman, N.Y.S.S., Hon'ble Shri Sagarji Dattaji Meghe, Secretary N.Y.S.S., Hon'ble Shri Sameerji Dattaji Meghe, Treasurer, N.Y.S.S., and our Principal, Dr. Uday P.Waghe who provided us with all the facilities requires for this paper.

Finally, we thank GOD, our parents, my husband and my lovely cutest daughter Runali Jayant Sakhare for their moral support and constant encouragement.

\section{REFERENCES}

[1] Rybach, Ladislaus (September 2007), "Geothermal Sustainability" (PDF), Geo-Heat Centre Quarterly Bulletin (Klamath Falls, Oregon: Oregon Institute of Technology) 28 (3), pp. 2-7, ISSN 0276- 1084 , retrieved 9 May 2009.

[2] John W. (June 2007), "Characteristics, Development and utilization of geothermal resources" (PDF), Geo-Heat Centre Quarterly Bulletin (Klamath Falls, Oregon: Oregon Institute of Technology) 28 (2), pp. 1-9, retrieved 2009-04-16.

[3] Calvin WM, Coolbaugh M, Kratt C, Vaughan RG. Application of remote sensing technology to geothermal exploration. In: Rhoden HN, Steininger RC, Vikre PG, editors. Geological society of Nevada symposium 2005: window to the world, Reno, Nevada. 2005. p. 1083-89.

[4] Shah M, Sircar A, Vaidya D, Sahajpal S, Chaudhary A, Dhale S. Overview of geothermal surface exploration methods. Int J Adv Res Innov Ideas Educ. 2015;1(4):55-64.

[5] Vaidya D, Shah M, Sircar A, Sahajpal S, Dhale S. Geothermal energy: exploration efforts in India. Int J Latest Res Sci Technol. 2015;4(4):1-23.s.

[6] Olson, T. (1998). Export opportunities abound for geothermal technologies. Geothermal Resources Council Bulletin 27:5, 137-138.

[7] Fridleifsson, I. (1997). Worldwide status of geothermal development and international cooperation. Transactions - Geothermal Resources Council 21, 347-353.

First Author Prof. Trupti Deoram Tembhekar [Prof. Trupti Jayant Sakhare], Assistant Professor (UA) Department of Electrical Engineering Yeshwantrao Chavan College of Engineering, Nagpur, Maharashtra State, India. Mobile No. 8830328743

Second Author Dr.S.N.Dhurvey, Assistant Professor (UA) Department of Electrical Engineering, PIET, Nagpur, Maharashtra State, India. 